\author{
: 623.4.016(477) \\ . . ндрієнко, . . люс ренко, . . олесник \\ ввівський інститут ухопутних військ, ввів
}

озглянутий методичний підхід до оцінки імовірності вр ження бойових м шин піхоти, який грунтується н вр хув нні кількісних $m$ якісних $n$ р метрів сн рядного н в нт ження, $m$ кож $x$ р ктеристик конструкції елементів броньового з хистум шин $m$ кого кл су.

лючові слов : бойов м шин піхоти, броня, $m$ ктичн ді гр м, бронез хист, бронепробиття.

\section{ступ}

ост нов к проблеми. н чні зміни поглядів н форми т способи ведення бойових дій в суч сних умов х істотно підвищили роль бойових м шин легкої к тегорії в ги, особливо бойових м шин піхоти ( $)$, що обумовлено низкою причин, у тому числі вимог ми до мобільності т втономності дій військ [1]. ри формув нні вигляду перспективної 3 метою економії ч су і 3 собів необхідно вр ховув ти можливість з стосув ння різних конструкторсько -технологічних рішень, спрямов них н підвищення рівня іiї бойових вл стивостей, особливо з хищеності.

н ліз ост нніх досліджень і публік цій. безпечення з хишеності було і з лиш ється кту льним з вд нням з умови постійного удоскон лення з собів їх ур ження. осягнутий н сьогодні рівень броньового з хисту у зв'язку 3 підвищенням ур ж ючої зд тності боєприп сів вже не може повною мірою з безпечити вимоги щодо ії 3 хищеності. дним з основних ет пів з безпечення необхідного рівня з хищеності м шин цього кл су є точн оцінк імовірності їх ур ження н полі бою 3 ур хув нням кількісних і якісних п р метрів сн рядного н в нт ження, т кож х р ктеристик конструкції елементів броньового з хисту ( ).

ерез неможливість зробити неур зливою 3 р хунок бронюв ння з усіх можливих н прямків обстрілу для різних ділянок бронюв ння призн ч ється і з безпечується різн сн рядостійкість. г льний рівень 3 хисту м шини оцінюється 3 допомогою $\mathrm{T}$ к ді гр ми сн рядостійкості, що являє собою сукупність з мкнутих кривих, побудов них для всіх основних броньових дет лей корпус т 6 шти [2].

ді гр мою можн судити про ступінь небезпеки, пов'яз ної з визн ченими н прямк ми і д льностями розт шув ння вогневого з собу, що обстрілює визн ченим типом боєприп сів. ншими слов ми, можн визн чити безпечні для (при обстрілі цим вогневим 3 собом) кути м неврув ння i

( ) . . ндрієнко, . . люс ренко, . . олесник д льності обстрілу. тже, чим менш сум рн площ, обмежен кривими т ктичної ді гр ми, тим вище 3 хищеність м шини.

дн к т ктичн ді гр м не вр хов ує неодн кові імовірності обстрілу із різних н прямків, влучність стрільби вогневого з собу, т кож різном ніття умов обстрілу. се це обумовило перехід до більш високого рівня уз г льнення при оцінці т формув нні вимог до 3 хищеності м шин цього кл су. ок зником т кого рівня $є$ імовірність ур ження yp, уз г льнен

3 умов ми т з соб ми обстрілу. им вон менш, тим менші, в середньому, і втр ти [3].

ет ст тті. метою визн чення цієі імовірності необхідно вміти її обчи слюв ти в конкретних умов х обстрілу (обр ним вогневим з собом під визн ченим кутом н відомій д льності), т кож кількісно х р ктеризув ти розподіл з собів ур ження т умови обстрілу.

\section{сновний м тері л}

ідомо, що імовірність ур ження зн чною мірою з лежить від імовірностей виявлення, влучення т ур ження з умови влучення в неї і може бути под н в н ступному вигляді [3] :

$$
y p={ }_{8} \cdot{ }_{8 л} \cdot y p / 8 л,
$$

де ${ }_{в}$ - імовірність виявлення цілі; ${ }_{в л}-$ імовірність влучення в ціль; ур/вл - імовірність ур ження цілі 3 умови влучення в неї.

изн чення імовірності виявлення цілі ${ }_{8} 3$ ур хув нням впливу сукупності т ктико-технічних $\mathrm{x}$ р ктеристик ( ) под не в [4]. д лі пост є з вд ння розр хунку вл, визн чення якої зН чно спрощується 3 умови 3 вд ння точки прицілюв ння: для н стильних боєприп сів посередині погон б шти (в центрі лінії з'єдн ння корпус т 6 шти), для боєприп сів, що пікірують $\mathrm{i}$ п д ють, - в центрі видимої проекції к ртинну площину при відповідних зн ченнях вертик льних кутів обстрілу. мовірність влучення в 
ціль визн ч ється сум рною похибкою пострілу т розмір ми цілі, тому для іï оцінки використ ємо припущення:

-3 кон розсіюв ння при влученні в $\epsilon$ вип дковим і х р ктеризується величин ми розсіюв ння боєприп сів по висоті і боковому н прямку;

- бронебійн дія всіх типів боєприп сів при фіксов них умов х зустрічі 3 підпорядковується норм льному з кону розподілу і $є$ вип дковою величиною бронепробиття, як х р ктеризується функцією розподілу, м тем тичним сподів нням т середнім кв др тичним відхиленням.

p ховуючи те, що корпус і 6 шт

м ють ділянки з різними конструктивними х р ктеристик ми (товщин т м тері л броні, кут н хилу броньових дет лей тощо), які умовно можн проксимув ти н бором прямокутників, споч тку скорист ємося н йпростішим вип дком, коли стрільб здійснюється по прямокутному щиту (мішені). мовірність влучення сн ряд в прямокутник, сторони якого п р лельні головним осям еліпс розсіюв ння, визн ч ється 3 формулою [5]:

$$
\begin{aligned}
& { }_{\text {вл }}=\frac{1}{4} \cdot\left[\left(\frac{z+l_{\sigma}}{\sigma n}\right)-\left(\frac{z-l_{\sigma}}{\sigma n}\right)\right] \times \\
& \times\left[\left(\frac{y+l_{B}}{6 n}\right)-\left(\frac{y-l_{\theta}}{8 n}\right)\right],
\end{aligned}
$$

де - функція норм льного з кону розподілу (функція пл с ); $z, \quad y \quad-\quad$ геометричні координ ти центр прямокутник по ширині i висоті, м; $l_{\sigma}, l_{\theta}-$ н піврозміри прямокутник по

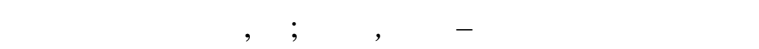
відхилення стрільби визн ченим типом боєприп с ів по боковому н прямку і висоті, м.

ля того, щоб перейти від функції пл с до приведеної функції пл с, необхідно кожен ргумент цієї функції перемножити н постійну величину $\rho$, що дорівнює 0,4769 [6]. ур хув нням цього вир з (1) н буде вигляду

$$
\begin{aligned}
& \quad{ }_{\text {вл }}=\frac{1}{4} \cdot\left[\left(\rho \cdot \frac{z+l_{\sigma}}{\sigma n}\right)-\left(\rho \cdot \frac{z-l_{\sigma}}{\sigma n}\right)\right] \times \\
& \times\left[\left(\rho \cdot \frac{y+l_{B}}{{ }_{6 n}}\right)-\left(\rho \cdot \frac{y-l_{B}}{{ }^{\prime} n}\right)\right] .
\end{aligned}
$$

ля проведення пр ктичних розр хунків з (2) необхідно зн ти розміри ур зливих зон i величини бn т $B_{\text {вn }}$, що з леж ть від зброї т боєприп сів, точності підготовки вихідних д них, підготовленості стріляючого т умов стрільби. ля типовим можн вв ж ти спосіб стрільби 3 місця по рухомій цілі [7, 8]. ур хув нням цього зн чення бn т $B_{6 n}$ розр ховуються 3 формул ми

$$
{ }_{B n}=\sqrt{\left(\begin{array}{l}
2 \\
\partial
\end{array}+\underset{B M}{2}+\underset{B \sigma}{2}+\underset{B 3 \beta}{2}\right) \cdot \operatorname{tg}^{2} \theta+\underset{B m}{2}+{ }_{B}^{2}},
$$

де $ә-$ похибки виміру д льності до цілі, т.д.;

вм - метеорологічні похибки, обумовлені невр хув нням ( бо невірним ур хув нням) ст ну тмосфери, темпер тури і тиску повітря, \% д льності; вб - б лістичні похибки, пов'яз ні з ур хув нням темпер тури і х р ктеристик п ртії порохового з ряду, зносу к н лу ствол , \% д льності; взв - похибки ур хув ння зміни відст ні між і ціллю від моменту виміру д льності до моменту здійснення пострілу, $\%$ д льності; $\theta$ - кут п діння сн ряд (н водиться в т блицях стрільби), гр д; вт - похибки технічної підготовки, обумовлені похибк ми при вивірці при цільних прил дь, пристрілки г рм ти, т кож н яв ністю з зорів у мех нізм х н ведення, т.д.; ${ }_{6}-$ похибки технічного розсіюв ння, пов'яз ні 3 серединними відхиленнями точок влучення сн рядів від точки прицілюв ння по висоті, т.д.;

$$
\sigma n=\sqrt{\frac{2}{\sigma m}+\frac{2}{\sigma \sigma}+\frac{2}{\sigma m}+\frac{2}{\sigma \kappa p}+\frac{2}{\sigma}},
$$

де $\sigma_{м}-$ метеорологічні похибки, що обумовлені невр хув нням ( бо невірним ур хув нням) ст ну тмосфери, темпер тури і тиску повітря, бокової скл дової швидкості вітру, \% д льності; бб - б лістичні похибки, пов'яз ні 3 ур хув нням темпер тури i $\mathrm{x}$ р ктеристик п ртії порохового з ряду, зносу к н л ствол, т.д.; бт - похибки технічної підготовки, обумовлені похибк ми при вивірці прицільних прил дь, пристрілки г рм ти, т кож н явністю $з$ зорів у мех нізм х н ведення, т.д.; бкр - похибки, пов'яз ні з ур хув нням крену

(точніше, з н хилом ц пф г рм ти), т.д.; 6 похибки технічного розсіюв ння, які пов'яз ні 3 серединними відхиленнями точок влучення сн рядів від точки прицілюв ння по боковому н прямку, т.д.

в ж ючи н те, що (як ціль) м є скл дну конфігур цію, імовірність влучення в ії силует може бути визн чен як сум імовірностей влучення сн рядів у кожну з ділянок

$$
{ }_{8 л}=\sum_{i=1}^{n}{ }_{8 л і},
$$

де $в л і-$ імовірність влучення боєприп сів в $i$-ий прямокутник; $n$ - кількість прямокутників, що проксимують поверхню

кщо по цілі зроблено $\kappa$ пострілів з одн кових умов, то імовірність влучення в ціль хоч 6 один р 3 обчислюється вир зом

$$
\text { вл } \quad к=1-\left(1-u_{1}\right) \cdot\left(1-u_{2}\right) \cdot\left(1-u_{1}\right),
$$


де $u_{1}, \quad u_{2}, \quad \iota_{\kappa}-$ імовірності влучення в ціль першим, другим, $\kappa$-им сн рядом.

вич йно, імовірність влучення в ціль дру гим т н ступними постріл ми буде вищою, ле в суч сних умов х ведення бойових дій вигр є той, хто першим виявив ціль т ур зив їі. ому при под льших розр хунк х ми 3 д ємо н Йскл дніші умови ведення бойових дій, вр ховуючи тільки імовірність влучення в ціль першою чергою. в ж ючи н те, що н г рм т 242 і вогонь по цілі ведеться короткими черг ми [7, 9], визн чення імовірності влучення в ціль однією чергою здійснюв лось 3 формулою

$$
{ }_{в л}=1-\left(1-u_{1}\right) \cdot\left(1-{ }_{u_{\kappa}}\right)^{N-1},
$$

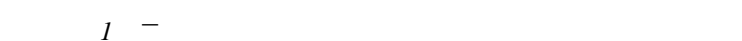
сн рядом; $\quad$ ик - імовірність влучення в ціль н ступними сн ряд ми; $N$ - кількість сн рядів у черзі.

об зн йти імовірність ур ження цілі з умови влучення в неї $у р / в л$, перш 3 все необхідно оцінити бронебійну дію сн рядів, під якою розуміють явище пробив ння боєприп с ми перешкод із броні бо проникнення їх у ці перешкоди [10]. роцес пробив ння броні н лежить до числ скл дних фізичних явищ, пов'яз них із швидкоплинними пл стичними деформ ціями м тері лу перешкоди. езв ж ючи н те, що ост нніми рок ми досить успішно розвив ються методи експеримент льного дослідження т ких процесів (високошвидкісн кінозйомк , рентгеноімпульсні уст новки тощо), мех нізм процесу дин мічної вз ємодії сн ряд й броні дост тньо не вивчений. ому оцінк ефективності бронебійної дії проводиться головним чином н основі н півемпіричних формул, кожн 3 яких вр ховує ті чи інші особливості конструкції сн ряд , вл стивості броні т умови зустрічі сн ряд 3 бронею.

ля оцінки х р ктеристики уд рної дії по обмеженій перешкоді (н прикл ді розр хунковий боєприп с приймемо 25-мм сн ряд до г рм ти 242 «ушм стер», що вст новлен н

22 «редлі». р ктеристикою уд рної дії приймемо н йменшу величину швидкості сн ряд в момент зустрічі $V_{\min }$, необхідну для пробиття перешкоди $з$ д ної товщини. ля бронебійних сн рядів $V_{\min }$ визн ч ється 3 н півемпіричною формулою коб-де- pp $[10,11]$

$$
V_{\text {min }}=K \cdot \frac{d^{0,75} \cdot b^{0,7}}{q^{0,5} \cdot \cos \alpha},
$$

де $V_{\text {min }}$ - мінім льн швидкість сн ряд, необхідн для пробиття перешкоди 3 д ної товщини, м/c; $K$ - коефіцієнт, що з лежить від вл стивостей броні т конструкції сн ряд ; $d-$ к лібр сн ряд , мм; $b$ - товщин перешкоди, мм; $q-\mathrm{M} \mathrm{c} \mathrm{сн} \mathrm{ряд,} \mathrm{кг;}$ $\alpha$-кут зустрічі сн ряд 3 перешкодою, гр д.

$$
V_{i}=V_{0} \cdot \exp \left(-2,67 \cdot 10^{-4} \cdot D\right) \text {. }
$$

стосовуючи формулу (4), величини $d$ i $b$ необхідно вир ж ти в дециметр х, тоді результ т буде отрим ний в м/с. еличин коефіцієнт $K$ колив ється в меж х 2000-3000 для сн рядів 3 притупленням т гетерогенної (неоднорідної) цементов ної броні, т кож для гостроголових сн рядів і гомогенної (однорідної) броні середньої і високої твердості. ля гомогенної броні низької твердості величин $K$ зн ходиться в меж х 1600 2000 [10]. вир зу (4) виплив $\epsilon$, що необхідн швидкість для пробиття броні зрост є зі збільшенням товщини броні т кут зустрічі. тже, для бронебійних сн рядів однієї конструкції зі збільшенням к лібру т м си сн ряд величин $V_{\min }$ зменшується.

p ховуючи те, що дист нція стрільби є величиною вип дковою і може зн ходитися в меж х 700-1300 м, для розр хунку імовірності ур ження бойової м шини необхідно зн ти швидкість зустрічі сн ряд 3 бронею, як в будь-якій точці тр єкторії його польоту $V_{i}$ розр ховується методом і ччі i проксимується з лежністю [12].

К вихідні для проведення розр хунків використ ємо д ні щодо розподілу броньового 3 хисту -2 н конструктивні елементи (т бл. 1), основні м лок ліберних втом тичних г рм т 3 рубіжних (т бл. 2) т зн чення серединних похибок стрільби для 25-мм г рм ти 242 « ушм стер» (т бл.3).

лід 3 зн чити, що розр хунок вл $к$ i

здійснюв вся з ур хув нням імовірностей обстрілу лобової, бортової т кормової проекцій досвідом лок льних війн і збройних конфліктів ост нніх десятиріч ці імовірності відповідно ст новлять: ${ }_{\lambda}=0,305 ; \quad \sigma=0,64 ;{ }_{\kappa}=0,055$ [13].

н ліз результ тів, одерж них з формул ми (3-5), пок зує, що імовірність ур ження з умови влучення в основні проекції -2 у 3 д ному ді п зоні д льностей дорівнюв тиме імовірності влучення в ці зони $y p / в л=$ вл, тому що бронебійн дія 25-мм сн ряд г рм ти 242 «шм стер» перевищує стійкість цієї м шини.

д лі, грунтуючись н вихідних д них, н ведених у т бл. 1, 2 і 3, розр хуємо імовірності влучення в $\quad-2$, результ ти яких под ні в т бл. 4. 
н ліз конструктивних елементів броньовогоз хисту -2

\begin{tabular}{|c|c|c|c|c|}
\hline йменув ння & Teni & & р д & , \\
\hline елементів корпус т б шти & Тері Л & н хилу до вертик лі, $\beta$ & зустрічі зі сн рядом, $\alpha$ & MM \\
\hline ерхній лобовий лист & $-70 ш$ & 80 & 80 & 6 \\
\hline $\begin{array}{l}\text { ист кришки моторно-тр нсмісійного } \\
\text { відділення }\end{array}$ & & 80 & 80 & 16 \\
\hline обовий сектор б шти & $-70 ш$ & $45-40$ & $45-40$ & 22 \\
\hline ортовий сектор б шти & $-70 ш$ & $37-28$ & $37-28$ & 18 \\
\hline ормовий сектор б шти & $-70 ш$ & $26-21$ & $26-21$ & 12 \\
\hline ерхній бортовий лист & $-70 ш$ & 67 & 67 & 16 \\
\hline ормов дет ль & $-70 ш$ & 13 & 13 & 18 \\
\hline ижній лобовий лист & $-70 ш$ & 56 & 56 & 18 \\
\hline ортов скул & $-70 ш$ & 60 & $82(71)$ & 14 \\
\hline ередній бортовий лист & $-70 ш$ & 22 & 22 & 16 \\
\hline ОПЛ ВКОВ Н КЛ ДК & оліурет н & 0 & 0 & 20 \\
\hline
\end{tabular}

сновні м лок ліберних втом тичних г рм т $з$ рубіжних

\begin{tabular}{|c|c|c|c|c|}
\hline \multirow{2}{*}{ йменув ння } & \multicolumn{4}{|c|}{ р їн -виробник } \\
\hline & р нція & & імеччин & еликобрит нія \\
\hline рк г рм ти & -693 & $\begin{array}{c}242 \\
\ll \text { ушм стер» }\end{array}$ & $\begin{array}{c}\text { DM 5 } \\
\text { Rh-202 }\end{array}$ & $\begin{array}{c}\text { L21 A1 } \\
\text { « рден» }\end{array}$ \\
\hline лібр, мм & 20 & 25 & 20 & 30 \\
\hline оменкл тур боєприп сів & $\mathrm{p}, \mathrm{p}$ & $\mathrm{p}(\mathrm{p})$ & & $\mathrm{p}, \mathrm{p}$ \\
\hline ОЧ тКОВ швидкість сн ряд , м/с & 1300 & 1100 & $1100-1300$ & 1200 \\
\hline ронепробиття ст левої броні, мм & $\begin{array}{l}20 \text { при } \alpha=60^{\circ}, \\
\text { Н } D=1000 \text { м }\end{array}$ & $\begin{array}{l}66 \text { при } \alpha=60^{\circ}, \\
\text { н } D=1000 \text { м }\end{array}$ & $\begin{array}{l}20 \text { при } \alpha=60^{\circ}, \\
\text { н } D=1000 \text { м }\end{array}$ & $\begin{array}{l}40 \text { при } \alpha=50^{\circ}, \\
\text { н } D=2000 \mathrm{M}\end{array}$ \\
\hline емп стрільби, постр/хв . & 700 & 900 & 1000 & $80-90$ \\
\hline льність ефективної стрільби, м & 2000 & $1800-2000$ & 1200 & - \\
\hline озсіюв ння, т.д. & 0,252 & 0,5 & 0,6 & 0,3 \\
\hline
\end{tabular}

блиця 3

н чення серединних похибок стрільби для 25-мм втом тичної г рм ти 242 « ушм стер»

\begin{tabular}{|c|c|c|c|}
\hline \multirow{2}{*}{ охибки стрільби } & \multicolumn{3}{|c|}{ ерединні похибки } \\
\hline & по н прямку, т. д. & по висоті, т. д. & по д льності, \% ц \\
\hline 1. охибки технічної підготовки & $E_{z^{1}}=0,3$ & $E_{y 1}=0,3$ & $E_{x T}=0,3 / \operatorname{tg} \theta_{C}$ \\
\hline \multicolumn{4}{|l|}{ 2. охибки визн чення д льності до цілі: } \\
\hline вдень (вночі); & - & - & ${ }_{\partial}=15(20)$ \\
\hline вдень (вночі); & - & - & $\partial=10(15)$ \\
\hline по шк л х прицілу; & - & - & ${ }_{\partial}=10$ \\
\hline окомірно н вивченій місцевості; & - & - & ${ }_{\partial}=6$ \\
\hline по к рті т 3 результ т ми пристрілки з кулемет ; & - & - & $\partial=4$ \\
\hline д лекоміром & - & - & $\begin{array}{l}\partial^{-3} \text { лежить від } \\
\text { типу д лекомір }\end{array}$ \\
\hline \multicolumn{4}{|l|}{ 3. охибки визн чення попр вок: } \\
\hline $\begin{array}{l}\text { н відхилення метеоб лістичних умов стрільби від } \\
\text { норм льних; }\end{array}$ & $E_{Z}=0,65$ & - & $E_{X}=1$ \\
\hline н крен & $E_{Z K P}=0,2$ & - & незн чні \\
\hline \multirow[t]{2}{*}{ H рух } & & & $o$ \\
\hline & \multicolumn{3}{|c|}{$\begin{array}{c}\text { (визн ч ються в з лежності від способу стрільби, н прямку і } \\
\begin{array}{cc}\text { швидкості руху } & \text { і цілі) }\end{array}\end{array}$} \\
\hline \multirow[t]{2}{*}{$\begin{array}{l}\text { 4. ум рні похибки підготовки (х р ктеризують } \\
\text { точність стрільби) }\end{array}$} & $E_{z n}$ & $E_{y n}$ & $E_{x n}$ \\
\hline & \multicolumn{3}{|c|}{ (визн ч ються для кожного способу стрільби) } \\
\hline \multicolumn{4}{|l|}{$\begin{array}{l}\text { озсіюв ння сн рядів (куль) (х р ктеризує } \\
\text { кучність стрільби) }\end{array}$} \\
\hline \multirow[t]{2}{*}{ 1. бличне (технічне) розсіюв ння } & 6 & 8 & $\partial$ \\
\hline & \multicolumn{3}{|c|}{ (н ведені в т блицях стрільби) } \\
\hline \multirow[t]{2}{*}{ 2. озсіюв ння моменту (способу стрільби) } & $6 c=z 6$ & ${ }_{B C}=y_{B}$ & $\partial c=x \partial$ \\
\hline & \multicolumn{3}{|c|}{ (визн ч ються в 3 лежності від способу т умов стрільби) } \\
\hline $\begin{array}{l}\text { ум рні похибки стрільби (х р ктеризують } \\
\text { влучність стрільби) }\end{array}$ & $6 n$ & ${ }^{8 n}$ & 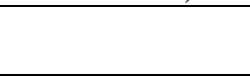 \\
\hline
\end{tabular}

( . . ндрієнко, . . люс ренко, . . олесник 
езульт ти розр хунку імовірності влучення в

блиия 4

\begin{tabular}{|c|c|c|c|c|c|c|c|c|}
\hline \multirow{2}{*}{\multicolumn{2}{|c|}{ роекції м шини }} & \multicolumn{7}{|c|}{ льність до цілі, м } \\
\hline & & 700 & 800 & 900 & 1000 & 1100 & 1200 & 1300 \\
\hline \multirow{3}{*}{$\begin{array}{c}\text { обов } \\
\text { проекція }\end{array}$} & ижній лист (зон 1 ) & 0,089 & 0,088 & 0,081 & 0,071 & 0,061 & 0,053 & 0,044 \\
\hline & ижній лист (зон 2$)$ & 0,036 & 0,035 & 0,032 & 0,027 & 0,023 & 0,02 & 0,017 \\
\hline & ШТ & 0,096 & 0,08 & 0,063 & 0,048 & 0,039 & 0,032 & 0,025 \\
\hline \multirow{3}{*}{$\begin{array}{c}\text { ортов } \\
\text { проекція }\end{array}$} & ШТ & 0,021 & 0,023 & 0,025 & 0,022 & 0,021 & 0,019 & 0,016 \\
\hline & $\begin{array}{c}\text { ередній т нижній } \\
\text { бортові листи }\end{array}$ & 0,008 & 0,012 & 0,02 & 0,024 & 0,029 & 0,03 & 0,028 \\
\hline & ерхній бортовий лист & 0,014 & 0,015 & 0,017 & 0,015 & 0,015 & 0,014 & 0,012 \\
\hline $\begin{array}{c}\text { ормов } \\
\text { проекція }\end{array}$ & орм & 0,023 & 0,023 & 0,021 & 0,018 & 0,015 & 0,013 & 0,011 \\
\hline \multicolumn{2}{|r|}{$B л \kappa$} & 0,096 & 0,095 & 0,095 & 0,085 & 0,08 & 0,073 & 0,063 \\
\hline \multicolumn{2}{|r|}{$B \Omega$} & 0,396 & 0,394 & 0,392 & 0,358 & 0,34 & 0,315 & 0,276 \\
\hline
\end{tabular}

\section{ИСНО В К И}

ким чином, з пропонов ний у роботі метод дозволяє оцінити вплив основних 3 собів їх ур ження н імовірність влучення вл Т

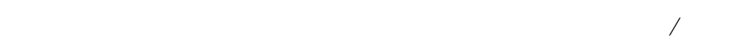
3 д них умов х обстрілу. дже в кінцевому результ ті він з безпечує більш точну оцінку імовірності вр ження н полі бою 3 ур хув нням кількісних i якісних п р метрі в сн рядного н в нт ження, т кож $\mathrm{x}$ р ктеристик конструкції елементів броньового з хисту.

\section{писок літер тури}

1. ержв вн прогр м розвитку бройних сил кр їни н 2006-2011 роки (основні положення). - .. рес кр їни, 2005. $-40 c$.

2. уров . . онструкция и р счёт $m$ нков / . уров. - . $\quad, 1973 .-602$ с

3. ом нов . . еория стрельбы из $m$ нков /

. ом нов. - . , 1973. -424 c.

4. ндриенко . . ценк влияния совокупности $m$ ктико-технических $x$ к ктеристик вероятность обн ружения цели / . . ндриенко // ртиллерийское и стрелковое вооружение. - 2006. - № 3. $-\quad$ 27-30.

5. сновы теории боевой эффективности $m$ нков // нки (основы теории, конструкции и боевой эффективности): 2 кн./ одред. проф. . . осик.$\therefore \quad$ 1983. - H.2. -121 c.
6. ентиель . . еория вероятностей /

. ентиель. - .: изм тлит, 1962. - 564 c.

7. орошкин . . уководство по действиям при вооружении боевой м шины пехоты -2 и пр вил м стрельбы / . . орошкин. - .. оенизд m, 1990.-128 c.

8. ндрієнко . . етодик оцінки впливу зн чень $m$ ктико-технічних $х$ ктеристик $\quad$ н імовірність викон ння бойового з вд ння мех нізов ним підрозділом / . . ндрієнко // руди к демї̈. - 2006. - № 67. - . 161 167.

9. блицы стрельбы для р внинных и горных условий 30-мм втом тической пушки 2 42. ( №08). - .. оенизд $m, 1986 .-40 c$

10. орофеев . . ви ционные боеприп сы / орофеев . ., орозов . ., ркисян . . - .. им. уковского, 1978. $-445 \mathrm{c}$.

11. орольков . . снов ния устройств и конструкция орудий и боеприп совн земной ртиллерии . орольков. - .. оенизд $m, 1976 .-459 c$.

12. н тюк. . ідвищення з хищеності м шин інженерного озброєння н гусеничному ш сі від суч сних з собів ур жсення методом вдоскон лення їх компоновки: дис. ... к нд. техн. н ук: 20.02.14 / . . н тюк. - ., 1999. $-220 c$.

13. льчук . . освід бойового з стосув ння військ, зброї $i$ військової техніки в лок льних війн $x i$ збройних конфлікт $x /$. . льчук, . . обко. - .. , 2001. $-119 c$.

дійщл доред киї 5.12.2008

ецензент: доктор технічних н ук, ст рший н уковий співробітник . . орольов, ьвівський інститут ухопутних військ, ьвів.

. . ндриенко, . . люс ренко, . . олесник

ссмотрен методический подходк оценке вероятности пор жения боевыхм шин пехоты, б зирующийся н учете количественных $и$ кчественных $n p$ метров сн рядной н грузки, $m$ кже $x p$ ктеристик конструкции элементов броневой з щиты м шин $m$ кого кл сc.

лючевые слов : боев ям шин пехоты, броня, $m$ ктическ яди гр мм, бронез щит, бронепробитие.

\title{
METHOD OF ESTIMATING THE PROBABILITY OF STRIKING OF INFANTRY FIGHTING VEHICLES DURING COMBAT OPERATION OF UNIFORM MILITARY FORMATIONS
}

\author{
A. M. Andriyenko, A. I. Sliusarenko, V. A. Kolesnik
}

Methodological approach to the estimating of probability of striking of infantry fighting vehicles, that is based on quantitative and qualitat ive parameters of projectile load, as well as characteristics of elements of armour protection of vehicles, belonging to this class is examined.

Keywords: infantry fighting vehicle, armour, tactical diagram, armour protection, armour piercing.

( ) . . ндрієнко, . . люс ренко, . . олесник 